\title{
Companies and the Constitutional 'Right to Life': A Critical Analysis of the Companies Act 71 of 2008
}

\author{
Siphethile Phiri
}

\author{
LLD Mercantile Law Candidate \\ University of South Africa
}

DOI: https://doi.org/10.36941/mjss-2021-0o61

\section{Abstract}

Corporate law is founded on the fictitious principle of the separate legal personality of a company. This principle entails that a company is a juristic person, separate and distinct from any persons involved with the company. Because of their juristic nature, companies can acquire rights and incur liabilities in their own capacity. This corporate-law principle is rooted in section 8(4) of the Constitution of the Republic of South Africa, 1996 (hereafter the Constitution) which expressly provides the Bill of Rights applies to juristic persons subject to the stated considerations. The fact that companies as juristic persons, similar to natural persons, are entitled to the rights and freedoms contained in the Bill of Rights reveals that the Constitution recognises companies as 'persons'. In this light, the article investigates how the Companies Act 71 of 2008 (hereafter the Companies Act) has embraced the constitutional right to life of companies as juristic persons as provided for in section 11 of the Constitution. To achieve this aim, the author applies the doctrinal legal research methodology - a legal research model which entails an examination of so-called 'black-latter law' with the Companies Act being the principal instrument. The results show that, although companies to do not enjoy the right to life in the same manner as natural persons, the literature examined reveals that the Companies Act recognises company's constitutional right to 'life'. In many instances, the right to continued existence of companies is promoted in various ways, including the introduction of the novel concept of business rescue by the Companies Act as a way of promoting the right to 'life' of companies.

Keywords: Companies Act, company law, juristic person, right to life, the Constitution, transformative constitutionalism

\section{Introduction}

The period between the promulgation of the interim Constitution (Act 200,1993) and the Constitution marked a huge change in many areas of the law. This period is known as a period of 'transformative constitutionalism'. Transformative constitutionalism entails a 'long term project' which commences with the enactment of a constitution, followed by its 'interpretation, and enforcement' in a manner which transforms "a country's political and social institutions and power relationships in a democratic, participatory, and egalitarian direction" (Klare,1998). According to Mupangavanhu, in simple terms transformative constitutionalism entails "the influence of the overarching values of the Constitution on the legal culture of interpretation to align it with the normative value system" (Mupantgavanhu, 2019). Through the lens of the law, transformative constitutionalism entails 
compliance with the values and principles of transformative constitutionalism. In his paper Mupangavanhu examines the impact of the Constitution's normative framework on the interpretation of provisions of the Companies Act (Mupangavanhu, 2019). The same tool is used in this article to establish whether companies enjoy the right to life as envisaged in section 11 of the Constitution.

It should always be borne in mind that South Africa is a constitutional state subject to the supremacy of the Constitution (Section 2 of the Constitution). This implies that no law or conduct may violate any provisions of the Constitution. Consequently, any law or conduct which is inconsistent with the Constitution is deemed to be invalid to the extent of its inconsistency.

Corporate law in South Africa is regulated mainly by the Companies Act which came into force in 2011. This Act repealed Companies Act 61 of 1973 (the 1973 Act), which was promulgated before the adoption of the Constitution. For this reason, it is inevitable that the 1973 Act fell short in complying with certain principles and values of transformative constitutionalism. Hence the need for a new statute which incorporates the principles and values of transformative constitutionalism. One of the purposes of the Companies Act is to "promote compliance with the Bill of Rights as provided for in the Constitution, in the application of company law" (Section $7(a)$ of the Companies Act). This shows that compliance with the Bill of Rights contained in the Constitution is one of the major purposes to be served by the Companies Act. In light of this provision, company law is required to promote, protect, and fulfil the Bill of Rights. By providing for this purpose - which the 1973 Act did not do we see that the Companies Act allows for the transformation of company law in line with the Constitution. We need, therefore, to consider whether the Companies Act in any way promotes the right to life in corporate law bearing in mind the provisions of section 8(4) of the Constitution.

Recently, the Council on Higher Education (CHE, 2008) advocated the transformation of the law as taught in South African universities. The CHE called for the internalisation of transformative constitutionalism within the LLB curriculum. This entails that the taught law must reflect the principles of transformative constitutionalism. This will, in turn, assist in excluding the teaching of law with little current relevance. Instead, law students will be taught extant law - the law which has been transformed in line with the transformative norms in the Constitution; the supreme law of the land. Hence, this article aims to reveal how corporate law has been transformed to include the constitutional right to life as a principle and value of transformative constitutionalism.

\section{The Constitution and the Right to Life}

The right to life is an imperative constitutional right. Section 11 of the Constitution provides that "[e]veryone has the right to life". The right to life cannot be limited when it comes to natural persons; not even during a state of emergency (Section 37(5)(c) of the Constitution). Violation of the constitutional right to life either intentionally (murder) or negligently (culpable homicide) constitutes a punishable offence. However, the position changes somewhat when we are dealing with companies. In certain justified circumstances, a company's right to 'life' may indeed be limited (Section 8(4) of the Constitution; section 79 of the Companies Act).

Of interest, before the adoption of the Constitution the death penalty was seen as an appropriate punishment which could be imposed on persons convicted of murder (Section 227(1)(a) of the Criminal Procedure Act 51, 1977). In its first case, S v Makwanyane, the Constitution Court had to find on the constitutionality of section 227(1)(i) of the Criminal Procedure Act 51 of 1977, which prescribed the death penalty as a competent sentence for murder. In that case, the Constitutional Court found that the death sentence was inhumane and degrading and violated the constitutional right to dignity. In short, the death penalty was found to be unconstitutional on that it can no longer be imposed by the courts. Thus, every person, including those already convicted, were seen to have a constitutional right to have their right to life respected and protected.

It is trite law that life commences at live birth and runs until death (Giles, 2011). Therefore, only individuals who are born alive are entitled to the constitutional right to life. This constitutional entitlement is valid for the duration of life and terminates automatically on death. A person is 
deemed to be dead when declared as such by a certified medical practitioner and once a death certificate has been issued. Therefore, in law, the unborn child has no claim on the right to life (Giles, 2011; Christians Lawyers Association of South Africa E Others v Minister of Health E Others 19984 SA 1113 (T) $1121 \mathrm{G}-\mathrm{H})$. Hence, to protect the interests of the unborn child where there is a benefit, the law of persons has developed the legal fiction known as the 'nasciturus rule'. In terms of the nasciturus fiction, where a benefit exists, an embryo is deemed to have been born alive for purposes of the benefit - provided, of course, that the unborn child is later born alive and be able to benefit (Pinchin and Another NO v Santam Insurance Co Ltd 19632 SA 254 (W); Christians Lawyers Association of South Africa $\mathcal{E}$ Others $v$ Minister of Health $\mathcal{E}$ Others 19984 SA 1113 (T) $1121 \mathrm{~B}-\mathrm{D})$. Where the unborn child fails to survive to birth, the benefit falls away automatically.

Having addressed when the entitlement to the constitutional right to life commences, it is also imperative to establish who qualifies for the right to life under section 11 of the Constitution. It is unanimously accepted that the rights in Chapter 2 of the Constitution applies universally to all natural persons (Section 7(1) of the Constitution). Section 8(4) of the Constitution provides further that "[a] juristic person is entitled to the rights in the Bill of Rights to the extent required by the nature of the rights and the nature of that juristic person". This implies that as juristic persons, companies are also entitled to the constitutional rights subject the conditions set out in section 8(4) of the Constitution. The question arising at this point is, given the nature of the constitutional right to life, do companies qualify to benefit from of this imperative constitutional right? If so, how and to what extent?

\section{Companies and the Constitutional Right to Life}

When interpreting the Bill of Rights, it is a constitutional imprimatur that a court, tribunal, or forum must promote the values that underlie an open and democratic society based on human dignity, equality, and freedom (Section 39(1)(a) of the Constitution). This implies that the interpretation to be attached to the Bill of Rights must at all times serve the founding principles and values of the Constitution (Section 39(1)(a) of the Constitution read with the preamble to the Constitution). Section 39(2) of the Constitution further obliges every court, tribunal, or forum to promote the spirit, purport, and objects of the Bill of Rights when interpreting any legislation and when developing the common law or customary law. This constitutional tenet promotes the constitutional provisions of section 7(1) which perceives the Bill of Rights as the cornerstone of democracy in South Africa. This entails that the Bill of Rights must at all times be protected and upheld and that this constitutional tenet must be applied in the determination of whether companies, as juristic persons, are entitled to the constitutional right to life (Section 11 of the Constitution).

The Companies Act has incorporated this constitutional tenet by providing that: "[t]he Commission, the Panel, the Companies Tribunal or a court must promote the spirit, purpose and objects of this Act" (Section 158(b)(i) of the Companies Act). The first purpose of the Companies Act is to "promote compliance with the Bill of Rights as provided for in the Constitution, in the application of company law". Therefore, this shows that the Companies Act, as one of its major aims, purports to align company law with the underlying values and principles of the Bill of Rights - in short, the Companies Act aims to transform company law to fit within the constitutional paradigm.

Given its nature, the constitutional right to life is generally perceived as primarily applicable to natural persons. This is because, although companies are deemed to be legal subjects, they do not have a body or soul and lack a physical existence of their own. This qualifies the juristic status of a company as a mere legal fiction. Despite this challenge, companies are, in law, regarded as legal subjects (juristic persons) and entitled to certain constitutional rights such as the right to life though not in the same way as natural persons. Thus, the constitutional right to life can be limited in respect of juristic persons as discussed below. 


\subsection{When does a company's constitutional right to life commence?}

The constitutional right to life of a company, like that of a natural person, commences at 'birth'. A company qualifies as a juristic person and entitled to certain rights and freedoms upon registration of its incorporation. Registration of a company therefore marks the birth of a company. At that stage a company is considered to be a person with certain rights and freedoms but subject to section 19(1)(b)(i)(ii) of the Companies Act (See also section 8(4) of the Constitution).

Birth of a company is confirmed by section 19 of the Companies Act which regulates the legal status of companies and provides that:

From the date and time that the incorporation of a company is registered, as stated in its registration certificate, the company-

a. is a juristic person, which exists continuously until its name is removed from the companies register in accordance with this Act;

b. has all of the legal powers and capacity of an individual, except to the extent that -

c. a juristic person is incapable of exercising any such power, or having any such capacity; or

d. the company's Memorandum of Incorporation provides otherwise.

This section confirms the birth of companies as juristic persons with the entitlement to certain rights and freedoms. A company is deemed to be incorporated once the company's name has been entered in the register of companies and a certificate of registration has been issued by the Companies and Intellectual Property Commission (the Companies Commission) (Section 19(1) of the Companies Act). The certificate of registration serves as conclusive proof that a company has been duly incorporated. As from the date and time stated in the registration certificate, the company becomes a juristic person as indicated in the Companies Act (Section 19(1)(a)(b) of the Companies Act).

Section 19 of the Companies Act, apart from confirming the birth of companies, also confirms the provisions of section 8(4) of the Constitution which provides that the enjoyment of rights and freedoms by companies depends on the nature of the right and the nature of the juristic person in question (Section $19(b)(i)$ of the Companies Act). In addition, section 19 of the Companies Act limits the company's right to life by providing for the possibility of deregistration of companies, which marks the death of a company (limiting the right to life of a company). (Section 8(4) of the Companies Act). Furthermore, certain rights and freedoms of a company may be limited in terms of its Memorandum of Incorporation. (Section 19(1)(b)(ii)) of the Companies Act).

As the supreme law of the land, the Constitution requires that every piece of legislation must promote the constitutional values and principles (Section 2 of the Constitution; preamble to the Constitution). Section 19(1) of the Companies Act upholds the values stated in section 8(4) of the Constitution and so supports the constitutional tenet that companies are entitled to certain constitutional rights - among them the right to life. In addition to the provisions of section 8(4) of the Constitution, it should be noted that in company law, companies are regarded as entities endowed with certain rights, freedoms, and obligations rather than as simple businesses.

\section{Literature Review}

The fact that a company enjoys perpetual succession until it is removed from the register of companies makes it undisputable that companies enjoy the right to life as provided for in section 11 of the Constitution (Section 19(1)(a)(b) of the Companies Act; Van Dorsten, 1991). Perpetual existence of a company was confirmed by Colman J in Stern $v$ Vesta Industries (Pty) Ltd E Another 19761 SA 81 (W) where it was held that a company is a legal person, and remains as such despite changes in its shareholding and/or its controlling minds. In other words, perpetual existence of a company implies that, notwithstanding changes in the membership of a company through transfer of shares or any other reason, a company retains its legal identity and continues to survive as such until its name is removed from the register of companies (Cassim \& Cassim, 2012; Maarsdorp v Haddow 19593 SA 861 
(C) 866 ).

The provision in the Companies Act which can be linked to the promotion of the "right to life" of a company, is the manner in which a company may be registered. If the name that a company chooses is found to be unsuitable, this could delay or prevent the registration of the company. Where an unsuitable name hinders the registration of a company, it hinders the company from being "born". Consequently, the company will be deprived the right to come into existence - to be born and to enjoy the "right to life" in the constitutional context. Hence, to promote companies' constitutional right to life, the Companies Commission may in certain circumstances use an interim name for purposes of registering a company until such time a suitable name is found (Section 11(1)(b) of the Companies Act). A company is said to be using an interim name as its registration if the company is registered using its registration number. Such promotes a company's right to come into existence or its constitutional right to life. On the other hand, if the registration of a company is refused on the basis of it having proposed an unsuitable name, that would limit or deprive the company of its constitutional right to life. Thus, an interim name is used to promote this constitutional right of companies.

In addition, the Companies Act provides in its preamble that the Act aim "[t]o provide for the incorporation, registration, organisation and management of companies". For this reason, the registration of companies has been simplified in various ways compared to their registration under the 1973 Act. We can therefore see that the Companies Act guarantees flexibility and simplicity in the formation and maintenance of companies (Section $7(b)($ ii) of the Companies Act). In addition, unlike under the 1973 Act, it is no longer a requirement that the Companies Commission should issue the certificate of commencement; once a certificate of registration has been issued, the company may start operating.

Conspicuously, the Companies Act does not promote the right to life of domestic companies alone, but also that of foreign companies which intend to conduct its business within the Republic of South Africa (Preamble to the Companies Act). To this end the Companies Act permits the transfer of registration of foreign companies to the Republic of South Africa (Section 13(5) of the Companies Act). This not only promotes the continued existence of foreign companies in the Republic of South Africa, but also the constitutional right of freedom of movement of such companies as legal subjects (Section 21 of the Constitution).

\section{Limitation of a Company's Constitutional Right to Life}

Section 19(1)(a) of the Companies Act, which provides for the juristic personality status of a company upon registration of its incorporation (birth of a company), at the same time creates the possibility to limit the right to life of companies by stipulating that:

From the date and time that the incorporation of a company is registered, as stated in its registration certificate, the company -

a. is a juristic person, which exists continuously until its name is removed from the companies register in accordance with this Act.

This provision shows that, at a certain point or subject to certain circumstances, the name of a company may be removed from the register of companies, which marks an end to the company's right to life (death of a company) so limiting the constitutional right to life of the company. Section 19 of the Companies Act, by providing that a company may lose its juristic personality, shows that a company's right to life is not an absolute right as enjoyed by natural persons. Thus, the right to life of companies may be limited subject to certain justifiable circumstances provided for in the Companies Act. It should be borne in mind that removal of a company's name from the register of companies marks an end to the company's right to life. The company ceases to be a juristic person and loses its entitlement to any rights and freedoms which may have applied to it (Section 19(1)(a) of the Companies Act). Thus, like natural persons, companies are entitled to the constitutional right to life from birth until death - i.e., from their incorporation and registration until they are dissolved by 
removal of their names from the companies register.

A company may be dissolved and have its name removed from the register of companies through winding-up - for example, where a solvent company is dissolved or wound up either voluntarily or in terms of a court order (Sections 79(1)(a)(b), 8o, 81 \& 82 of the Companies Act). Voluntary winding-up of a solvent company takes place through the adoption of a special resolution to wind the company up, either by the company itself or by its creditors (Section $80(1)$ of the Companies Act). Voluntary winding-up commences when a special resolution adopted to wind up the company has been filed with the court under section 8o(2) of the Companies Act (Section 8o(6) of the Companies Act).

On the other hand, winding-up of a solvent company in terms of an order of court may be instituted on various grounds set out in the Companies Act. Section 81(1) of the Companies Act provides that a solvent company may be wound up in terms of a court order where:

b. the company has -

i) resolved, by special resolution, that it be wound up by the court; or

ii) applied to the court to have its voluntary winding-up continued by the court;

c. the practitioner of a company appointed during business rescue proceedings has applied for liquidation in terms of section $141(2)(a)$, on the ground that there is no reasonable prospect of the company being rescued; or

d. one or more of the company's creditors have applied to the court for an order to wind up the company on the grounds that -

i) the company's business rescue proceedings have ended in the manner contemplated in section $132(2)(b)$ or $(c)(i)$ and it appears to the court that it is just and equitable in the circumstances for the company to be wound up; or

ii) it is otherwise just and equitable for the company to be wound up;

e. the company, one or more directors or one or more shareholders have applied to the court for an order to wind up the company on the grounds that -

i) the directors are deadlocked in the management of the company, and the shareholders are unable to break the deadlock, and -

aa) irreparable injury to the company is resulting, or may result, from the deadlock; or

ab) the company's business cannot be conducted to the advantage of shareholders generally, as a result of the deadlock;

ii) the shareholders are deadlocked in voting power, and have failed for a period that includes at least two consecutive annual general meeting dates, to elect successors to directors whose terms have expired; or

iii) it is otherwise just and equitable for the company to be wound up;

f. a shareholder has applied, with leave of the court, for an order to wind up the company on the grounds that -

i) the directors, prescribed officers or other persons in control of the company are acting in a manner that is fraudulent or otherwise illegal; or

ii) the company's assets are being misapplied or wasted; or

g. the Commission or Panel has applied to the court for an order to wind up the company on the grounds that -

h. the company, its directors or prescribed officers or other persons in control of the company are acting or have acted in a manner that is fraudulent or otherwise illegal, the Commission or Panel, as the case may be, has issued a compliance notice in respect of that conduct, and the company has failed to comply with that compliance notice; and

i) within the previous five years, enforcement procedures in terms of this Act or the Close Corporations Act, 1984 (Act No. 69 or 1984), were taken against the company, its directors or prescribed officers, or other persons in control of the company for substantially the same conduct, resulting in an administrative fine, or conviction for an offence. 
However, for a shareholder to apply to a court for the winding-up of an insolvent company as contemplated in section $81(1)(d)$ or $(e)$ of the Companies Act, that shareholder must

have been a shareholder for a continuous period for at least six months immediately before the date of the application or have become a shareholder as a result of: (i) acquiring another shareholder; or (ii) the distribution of the estate of a former shareholder and the present shareholder and other or former shareholder, in aggregate (Section 81(2) of the Companies Act).

The limitation of the constitutional right to life of companies may also take place through deregistration of a company by the Companies Commission on the grounds listed in section 82(3) of the Companies Act. However, section 82(4) of the Companies Act provides further that: "[i]f the Commission deregisters a company as contemplated in subsection (3), any interested person may apply in the prescribed manner and form to the Commission, to reinstate the registration of the company". This provision aims to promote the company's constitutional right to life - a fundamental right in corporate law - in that once a company has been removed from the register of companies and ceased to exist, the possibility exists for it to be "re-born" through reinstatement to the register.

It should be noted that during the winding-up period, be it voluntarily or in terms of a court order, the company remains a juristic person and retains all its powers and rights (Section 8o(8)(a) of the Companies Act). The company only loses its juristic status once it has been wound up and dissolved. Thereafter, it will no longer be considered a legal person and, therefore, no longer entitled to any rights and freedoms. Section 83 of the Companies Act explains when a company is considered to have been dissolved. It provides:

A company is dissolved as of the date its name is removed from the companies register unless the reason for the removal is that the company's registration has been transferred to a foreign jurisdiction, as contemplated in section $82(5)$.

\section{Business Recue and the Constitutional Right to Life of Companies}

Although, a company's constitutional right to life may be limited in terms of certain provisions in the Companies Act, the same Act has introduced the innovative concept of business rescue, also known as corporate rescue. The primary aim of business rescue is to promote and protect a company's right to life in that it enables the resuscitation of dying companies. In its preamble, the Companies Act provides that the Act aims "to provide for efficient rescue of financially distressed companies". Business rescue of financial distressed companies is regulated by Chapter 6 of the Companies Act.

Before turning to the statutory provisions governing corporate rescue, it is of paramount importance to note that section $7(k)$ of the Companies Act provides that one of the purposes of the Act is to "provide for the efficient rescue and recovery of financially distressed companies, in a manner that balances the rights and interests of all relevant stakeholders". This points to the commitment of the Companies Act to promote and protect the constitutional right to life of companies. In light of this aim, it is clear that rescuing a company is preferable than to liquidating it.

Corporate rescue is generally described as a process of enabling financially struggling companies to return to a state of viability and to prevent them from becoming insolvent (Dignam \& Lowry, 2016). In terms of the Companies Act:

"[B] usiness rescue" means proceedings to facilitate the rehabilitation of a company that is financially distressed by providing for -

i) the temporary supervision of the company, and of the management of its affairs, business and property;

ii) a temporary moratorium on the rights of claimants against the company or in respect of property in its possession; and

iii) the development and implementation, if approved, of a plan to rescue the company by restructuring its affairs, business, property, debt and other liabilities, and equity in a manner that maximises the likelihood of the company continuing in existence on a solvent basis or, if it is not possible for the company to so continue in existence, results in a better return for 
the company's creditors or shareholders than would result from the immediate liquidation of the company (Section 128(1)(b) of the Companies Act).

Binns-Ward J in Koen v Wedgewood Village Golf \& Country Estate (Pty) Ltd, 20122 SA 378 (WCC) held that:

Business rescue is intended to serve that public interest by providing a remedy directed at avoiding the deleterious consequences of liquidations in cases in which there is a reasonable prospect of salvaging the business of a company in financial distress, or of securing a better return to creditors than would probably be achieved in an immediate liquidation (Para 14 and cf Nwafor, 2017).

In African Banking Corporation of Botswana Ltd v Kariba Furniture Manufacturers (Pty) Ltd, 20153 All SA 10 (SCA) Leach JA, also stated that:

I am mindful of the warning by this court in Oakdene against being prescriptive about the assessment of reasonable prospects of rescue. But there can be no dispute that the directors voting in favour of a business rescue must truly believe that prospects of rescue exist and such belief must be based on a concrete foundation.

There are two ways of placing a company under business rescue: through adoption of a voluntary resolution by the company's board of directors; (Section 129(1) of the Companies Act) or in terms of an order of court where an application has been instituted by an affected person to have the company placed under business rescue (Section 131(1) of the Companies Act). The Act defines an affected person in relation to a company, to mean:

i) a shareholder or creditor of the company;

ii) any registered trade union representing employees of the company; and

iii) if any of the employees of the company are not represented by a registered trade union, each of those employees or their respective representatives (Section 128(1)(a) of the Companies Act).

Once a company has been placed under business rescue, it is the duty of the business rescue practitioner to come up with a rescue plan for the company. In Nedbank Ltd v Bestvest 153 (Pty) Ltd 20125 SA 497 (WCC) it was stated that

...it should be left up to the business rescue practitioner to formulate the rescue package once he/she has had an opportunity to properly assess the company, its prospects going forward and, most importantly the reasons for its commercial distress (Para 41).

The adoption of the rescue plan must take place as provided in section 150 of the Companies Act.

Where an application is made to court for the rescue of a company, the court has a discretion after considering the evidence adduced, to decide whether to place the company under business rescue (Section 131(4) of the Companies Act). The burden of proof lies with the applicant to show, on a balance of probabilities, that the company concerned is in financial distress but that there is a reasonable prospect that it may be rescued (Koen and Another $v$ Wedgewood Village Golf and Country Estates (Pty) Ltd and Others 20122 SA 378 (WCC) para 17). Thus, in so doing promoting the company's right to continued existence. However, where there is no reasonable prospect of rescuing a financially distressed company, the court is left with no choice but rather to order the liquidation and dissolution of the company (Sections 79-83 of the Companies Act). Liquidation and dissolution of a company have a negative impact on its constitutional right to life as it marks the end of the company's life, and other rights and freedoms.

\section{Conclusion}

From the discussion above, it cannot be disputed that the Companies Act promotes the constitutional right to life of companies in numerous ways. The most prominent of these is through the introduction of the innovative concept of business rescue which is aimed at promoting the right to life of financially distressed companies which have a reasonable prospect of being rescued from their debts. However, unlike natural persons, the constitutional right to life of companies may be limited 
in certain justified circumstances.

\section{References}

African Banking Corporation of Botswana Ltd v Kariba Furniture Manufacturers (Pty) Ltd 20155 SA 192 (SCA); 20153 All SA 10 (SCA).

Bourne, H. (1998). Principles of Company Law. Sydney London: Cavendish Publishing Ltd.

Cassim, F.H.I. (2011). The Practitioner's Guide to the Companies Act 71 of 2008. Cape Town: Juta \& Co Ltd.

Cassim, F.H.I. \& Cassim, M.F. (2012). Contemporary Company Law. Claremont South Africa: Juta \& Co.

Christians Lawyers Association of South Africa \& Others v Minister of Health \& Others 19984 SA 1113 (T) 1121 G-H.

Council on Higher Education "Decolonising the curriculum: stimulating debate Purpose", http://www.che.ac.za/sites/default/files/publications/BrieflySpeaking\% 20\%283\%29\%20Curriculum\%2odecolonisation.pdf (accessed on 14 August 2018).

Council on Higher Education "The State of the provision of the Bachelor of Laws (LLB) qualification in South Africa", https://www.che.ac.za/media and_publications/accreditationand-national-reviews/state-provisionbachelor-laws-llb (accessed on 8 March 2020).

Constitution of the Republic of South Africa Act 108 of 1996.

Criminal Procedure Act 51 of 1977.

Giles, S.P. (2011). Giles SP. Gospel and Constitutional Imperatives: The right to life. In die Skriflig 45(1), 57-76.

Klare, K.E. (1998). Legal Culture and Transformative Constitutionalism. South African Journal on Human Rights 14, 146-188.

Koen and Another v Wedgewood Village Golf and Country Estates (Pty) Ltd and Others 20122 SA 378 (WCC).

Langa, P. (2006). Transformative Constitutionalism. Stellenbosch Law Review 17, 351-36o.

Maarsdorp v Haddow 19593 SA 861 (C) 866.

Mupangavanhu, B.M. (2019). Impact of the Constitution's Normative Framework on the Interpretation of Provisions of the Companies Act 71 of 2008. Potchefstroom Electronic Review/ Potchefstroom Electronic Law Journal 22, 1-24.

Nedbank Ltd v Bestvest 153 (Pty) Ltd 20125 SA 497 (WCC).

Pinchin and Another NO v Santam Insurance Co Ltd 19632 SA 254 (W).

Van Dorsten, J.L. (1991). South African Business Entities: A Practical Guide. South Africa: Obiter Publishers. 